Bryn Mawr College

Scholarship, Research, and Creative Work at Bryn Mawr College

Classical and Near Eastern Archaeology Faculty

Research and Scholarship

Classical and Near Eastern Archaeology

1965

\title{
The East Pediment of the Siphnian Treasury: A Reinterpretation
}

Brunilde S. Ridgway

Bryn Mawr College, bridgway@brynmawr.edu

Let us know how access to this document benefits you.

Follow this and additional works at: https://repository.brynmawr.edu/arch_pubs

Part of the History of Art, Architecture, and Archaeology Commons

\section{Custom Citation}

Ridgway, Brunilde S. 1965. "The East Pediment of the Siphnian Treasury: A Reinterpretation." American Journal of Archaeology 69.1: $1-5$

This paper is posted at Scholarship, Research, and Creative Work at Bryn Mawr College. https://repository.brynmawr.edu/arch_pubs/174

For more information, please contact repository@brynmawr.edu. 


\title{
The East Pediment of the Siphnian Treasury: A Reinterpretation
}

\author{
BRUNILDE SISMONDO RIDGWAY
}

PLATES 1-2

Archaeologists have been unanimous in praising the continuous sculptured frieze crowning the walls of the Siphnian Treasury in Delphi; but the east pediment of this building, the only one sufficiently preserved to allow detailed examination, has attracted a different kind of scholarly attention and comment. While many writers have stressed the importance of this pediment for the history of architectural sculpture, almost as many have qualified this judgment with unfavorable remarks on its poor execution and unsatisfactory composition.

Important the Siphnian pediment is, though perhaps not as important as it was thought in the past, when it was held to represent the tangible transition of tympanal decoration from low to high relief and finally to sculpture in the round. ${ }^{1}$ A reappraisal of the poros pediments from the Athenian Akropolis has shown that these various techniques of decoration could be employed not only at the same time but perhaps even on the same building, and hence bear no chronological or evolutionary significance. ${ }^{2}$ The master of the Siphnian pediment, however, still deserves credit for introducing crouching grooms and reclining figures as plausible filling for the awkward space toward the extremities of the tympanon, created by the sloping eaves of the roof. $^{3}$ Furtwängler, ${ }^{4}$ Picard and De la Coste-Messelière, ${ }^{5}$ Poulsen, ${ }^{6}$ Lapalus, ${ }^{7}$ and Richter, ${ }^{8}$ to quote only some of the best known authors who have written on the subject, have all stressed this point and agree in seeing in the small Siphnian gable a forerunner of the more imposing east pediment of the temple of Zeus at Olympia.

\footnotetext{
1 Because of the bench-like projection of the tympanon wall, to which the figures adhere from the waist down.

2 For the latest opinion on the subject see W.-H. Schuchhardt, "Archaische Bauten auf der Akropolis von Athen," $A A$ (1963) cols. 797-824, esp. cols. 815-816. His views were expressed in lectures at Princeton and Bryn Mawr during the academic year 196I-62.

${ }^{3} \mathrm{~A}$ fallen giant, of course, appears in the earlier Corfu Pediment, but its head lies at the very corner, in a position which almost excludes the figure from the already fractioned composition of the whole. The wounded or lunging giants
}

Reduction of a figure's height by pose and movement rather than by diminution of scale should serve the purpose of unifying a composition. This however is not yet the case with our Treasury. Whether, with Richter, we see in the pediment the representation of a single story, or, with Picard, De la Coste-Messelière and Lapalus, a central episode flanked by unrelated themes, we are forced to admit that a marked discrepancy exists among the figures within the triangular frame. Other faults usually detected in the Siphnian pediment are the lack of balanced symmetry, the direction of the movement to the right (more appropriate to a continuous frieze than to a contained tympanon), the monotonous effect of the vertical accents in the center, the awkward execution. These faults are real; they may be overemphasized (as in Poulsen) or understressed (with Lapalus), but cannot be denied. On one count, however, the sculptor might plead "not guilty," and the apparent awkwardness might be due to imperfect preservation of the figures, which affects our understanding of the scene. I refer to the large scale of the central personage in the composition, who towers over the two contestants for the tripod, Herakles and Apollo.

By unanimous agreement this key figure has been identified as Athena, notoriously a staunch supporter of Herakles in all his deeds and frequently depicted in this capacity in representations of "The Struggle for the Delphic Tripod." This rather obscure episode in the life of the hero was very popular in antiquity, as attested by the large number of black-figure and red-figure vases illustrating

of the Peisistratid temple on the Athenian Akropolis are contemporary with, and probably even slightly later than, the Siphnian sculptures.

4 Aegina (Munich 1906) 318.

5 FdeD IV:2 (Paris 1928) 153-162.

${ }^{6}$ Delphi (London 1920) rog-ri I.

${ }^{7}$ Le fronton sculpté en Grèce (Paris 1947) 128-130; 272 and passim.

${ }^{8}$ Sculpture and Sculptors of the Greeks (New Haven 1950) I2I. 
it, as well as by other works, some extant and some known only through literary references. ${ }^{9}$ In Delphi itself, besides the Siphnian pediment, another archaic monument told the story: a group by three Corinthian artists set up by the Phocians "at the time when Tellias the Elean led them against the Thessalians." ${ }^{10}$ According to Pausanias' description, this dedication included statues of Herakles and Apollo grasping the tripod, and of Leto and Artemis trying to soothe Apollo, while Athena was "doing the same by Herakles." It has generally been assumed that the anonymous master of the Siphnian pediment adapted a paratactic representation of this sort to the requirements of his gable. The sculptor, according to Furtwängler, by "arbitrarily" making one figure a head taller than the others, converted a continuous and presumably isocephalic frieze into a triangular composition balanced on the axis of the one personage whose movement in two directions was most appropriate for a central emphasis. ${ }^{11}$

By selecting as axis one of four figures, the master was confronted with an unbalanced distribution of personages on either side, but he compensated for the discrepancy in number by making Herakles stride vigorously, thus filling more than the space usually allotted to a single figure. ${ }^{12}$ Lapalus ${ }^{13}$ can therefore write: "l'échelle des personnages s'adapte assez bien à la double inclinaison des rampants," and "la décoration médiane du fronton est acceptable, en ce qui concerne sa composition." But can we really accept an Athena so much taller than both the strong man of antiquity and the most athletic of all Greek gods? Though such a stature may have been forced on the artist by compositional requirements, it symbolically glorifies the ally of the thief-and a feminine ally at that-over the Lord of Delphi. Could the hapless artist really have made such a faux-pas, or are we guilty of misinterpretation?

\footnotetext{
${ }^{9}$ Brommer, F., Vasenlisten zur griechischen Heldensage ${ }^{2}$ (Marburg 1960) 30-38. Lists and references also to other than ceramic representations in Luce, S., "Studies of the Exploits of Herakles on Vases, II: The Theft of the Delphic Tripod," $A J A$ 34 (1930) 313-333.

${ }^{10}$ Paus. I0.13.7-8, Frazer's trans. The fight between Phocians and Thessalians is related by Pausanias at greater length in I0.I.8-II; cf. Frazer's commentary, Vol. V, 214, where, on the basis of Herodotos, 8.27 , the event is dated "not many years" before Xerxes' invasion in 480 B.C.

11 Aegina 318. "Die ganze Mittelgruppe ist von einen als Fries komponierten Vorbilde entlehnt. Athena und Herakles, Apollo und Artemis sind vier völlig gleichwertige und gleichartige Figuren. Apollo und Herakles kämpfen um den Dreifuss;
}

None of the extant literary sources on the Struggle for the Tripod is contemporary in date with the Siphnian Treasury. The most detailed account, by Apollodoros, ${ }^{14}$ was probably written at the time of the Emperor Hadrian. Two more mentions of the myth, by Pausanias ${ }^{15}$ and Hyginus, ${ }^{16}$ date from the Antonine period. Both Apollodoros and Hyginus, however, used excellent ancient authorities and followed them faithfully; and Pausanias seems to know of poetical accounts lost to us, since he affirms that "the poets have taken up this story, and have sung of a fight between Herakles and Apollo for the tripod." ${ }^{17}$ We may assume, then, that Apollodoros had access to copious literary material more or less contemporary with the sculptural work, and that he faithfully related the version of the story common in the sixth century B.c. In his text, however, there is no mention of Athena, or indeed of any other spectator. The story is simple: Herakles had committed murder and was afflicted by incurable disease. He sought help from the oracle at Delphi, but the priestess refused to answer him. Therefore "he was fain to plunder the temple and, carrying off the tripod, to institute an oracle of his own. But Apollo fought him, and Zeus threw a thunderbolt between them. When they had thus been parted, Hercules received an oracle. . . ."18 Similarly Hyginus tells that Herakles returned the stolen tripod Iouis iussu. Zeus, therefore, and not Athena, is the central figure between the two contestants in the literary accounts. Could this be the case also in the sculptural version?

A central Zeus would satisfy all the iconographical requirements. Traditionally involved in the myth, he alone had the authority to separate his two sons, he alone had the physical and moral stature required to tower above them. No detail in the rendering of the central figure forces us to see it as female rather than male; some traits even point toward the latter identification.

Artemis hilft ihrem Bruder, Athena ihrem Liebling Herakles. Dies Frieskomposition hat der Künstler dadurch zur Giebelgruppe gestaltet, dass er Athena willkürlicherweise um einen Kopf grösser bildete und sie, deren Bewegung nach zwei Seiten gerichtet war, zur Mittelfigur machte" (my italics).

12 Cf. FdeD Iv:2, I 55

13 Op.cit. (supra n. 7) 230, 282.

14 Bibl. 2.6.2.

153.21 .8 and 10.13.7.

${ }^{16} \mathrm{Fab}$. 32.3 .

17 I 0.13 .8 , Frazer's translation. For a résumé of the sources and other references, see Luce, loc.cit. (supra n. 9).

18 Apollodoros, Bibl. 2.6.2, trans. Frazer, Loeb ed. My italics. 
DRESS

The central personage (pl. 2, fig. I) wears a long Ionic chiton covered by a heavier himation thrown symmetrically over both shoulders. This dress, though often worn by women, is by no means exclusively a feminine garb. In the Siphnian Treasury itself, the Zeus of the east frieze dons a similar crinkly garment under a diagonally draped mantle. ${ }^{19}$ In statuary in the round, the archaic youth from Pitane ${ }^{20}$ and that from Cape Phoneas ${ }^{21}$ are particularly significant because their chitons must, as in the pedimental figure, be girt at the waist under the diagonal mantle in order to form the mass of central folds falling between their feet. In relief work, one may compare the seated ruler of the Harpy Tomb ${ }^{22}$ or some figures of the Satrap sarcophagus in Istanbul. ${ }^{23}$ Beyond the Ionic sphere, the Akropolis youth $633^{24}$ wears not one but two such vestments. Zeus's garment in the Introduction Pediment from the Akropolis ${ }^{25}$ has a smooth surface but is obviously a sleeved chiton; similarly attired is the terracotta Zeus recently found at Paestum, ${ }^{26}$ and he also has heavy folds gathering between the legs.

Again on the basis of "internal" comparisons the Siphnian garb is more typically male than female: the other figures within the pediment (pl. I, fig. 2), unquestionably recognizable as feminine because of pronounced bosoms, wear a longer garment which distinctly trails behind them and dips over their feet at the front; the type of ankle-length skirt worn by the central deity appears again only in the first figure facing the horses on the left, and the sex of this figure is left uncertain in the original publication. ${ }^{27}$ This difference in length is respected also in the east frieze "Assembly of the Gods": contrast for instance Aphrodite's and Artemis' attire with that of Zeus. ${ }^{28} \mathrm{~A}$ parallel dif-

\footnotetext{
19 De la Coste-Messelière, P. \& Mirè, G., Delphes (Paris 1943) (henceforth quoted as Delphes) pls. 76-77.

20 Akurgal, E., Die Kunst Anatoliens (Berlin 1961) figs. 195197.

21 ibid. figs. 193-194. 22 ibid. fig. 88.

23 Kleeman, I., Der Satrapen-Sarkophag aus Sidon (Berlin 1958) pls. 3, I3-I4; cf. also pp. Io8-i I for a discussion on the long chiton worn by men, with bibliography and examples. On the same subject see also Picard, Ch., Les portes sculptées, Etudes Thasiennes 8 (Paris 1962) 156 and note I, and Marcadé, J., BCH 64 (1950) 195.

24 Payne, H. \& Young, G., Archaic Marble Sculpture (London 1950) pl. I02.

25 Heberdey, Altattische Porosskulptur (Vienna 1919) pl. I.

${ }^{26}$ Sestieri, BdA 40 (1955) 193-202.
}

ference exists in the length of the chiton's sleeves, which reach the elbow on female figures but are shorter on male ones, as well as on the central divinity of the pediment.

The himation worn symmetrically over both shoulders is used indifferently by men and women, as exemplified by various figures of the Siphnian frieze. Instances of this fashion among men are common in vase painting; ${ }^{29}$ in sculpture one may recall the Dionysos in combat with a giant on a metope from Selinos, ${ }^{30}$ the Charioteer relief from the Akropolis, ${ }^{31}$ or, for the mantle alone without the chiton, the famous Moschophoros ${ }^{32}$ and the so-called Ilissos Kouros. ${ }^{33}$

\section{HAIR-STYLE}

Long locks falling over the chest are appropriate to both female and male divinities. Again the best parallel is provided by the Zeus of the east frieze, and by several other male personages in the reliefs of the other sides. On the contrary, the goddesses assembled in the east frieze tend to wear their hair in long strands over the shoulders, with only short locks in front of the ears; Athena, on the east and north sides, has no parotides, her hair being gathered in a mass over her back; ${ }^{34}$ her figure on the west side is too badly damaged to allow speculation on her coiffure.

The central figure of the pediment displays unusual frontal locks, in that they are obliquely rather than vertically striated. Could this rendering be a way of indicating a personage of special distinction ? $^{35}$

\section{OTHER DETAILS}

The muscular build of the central deity, though not totally unsuitable for Athena, is more appropriate to a virile figure. The rendering of the chest is also masculine, with flattened breasts con-

\footnotetext{
${ }^{27}$ FdeD IV:2, 155.

28 Delphes pls. 76-77.

29 Among the most famous, cf., e.g., Peleus and others on the François vase, FR pls. I-2.

30 Temple F; Mirè Brothers, Sicile Grecque (Paris 1955) fig. 133. The commentary (by F. Villard) at p. 307 specifies that the identification is indeed made on the basis of the attire.

31 No. 1342; Payne, op.cit. (supra n. 24) pl. I27.

32 ibid. pl. 2.

33 Athens NM 3687 , Deltion I4 (I931-32) pls. 5-7.

34 Cf. FdeD IV:2, 85 and 104.

$35 \mathrm{~A}$ similar differentiation of hair-patterns is employed in the Sikyonian metope of the Cattle Raid to distinguish the Dioskouroi from their human companions; Delphes pl. 4I and fig. 15 at p. 25 .
} 
trasting markedly with the prominent bosoms of female figures of the pediment. The attitude of the god, though definitely not favorable to Apollo, is not openly favorable to Herakles either, as one would expect were the personage Athena. It seems likely that the missing left arm served to restrain Herakles, as the right one held back Apollo. ${ }^{36}$

Furthermore, whenever Athena appears in the Siphnian frieze, she is characterized by the aegis, and at times also by other warlike attributes. The central figure of the pediment has no such attribute preserved, nor could the missing head have been covered by a helmet because of the lack of space in the apex of the gable. Zeus need not be characterized by any symbol of power, as majestic stature coupled with a position of pre-eminence and a bearded head would be sufficient to identify the Father of Gods and Men.

Most convincing of all arguments is the fact that traces of a beard are indeed still visible in spite of the mutilation suffered by the sculpture (pl. I, fig. 3). On the deity's right shoulder, crossing the long locks over the chest and extending onto the himation, a projection of the stone appears, with the original surface roughly picked, as far as preserved, and a somewhat stunted triangular outline. This projection may at first be taken to represent the mass of hair falling over the back, as seen over the left shoulder, but, on comparison, it proves to be quite distinct from it and of approximately the same shape as Herakles' beard (pl. I, fig. 3 ). ${ }^{37}$ If these traces on the stone are, as seems possible, reconstructed into a beard, the personage would appear with his head sharply turned toward his right. This pose is not incompatible with the frontal position of the torso, as proved by the Herakles at his side; indeed, such a stance would impart to the central divinity that double direction envisaged by Furtwängler ${ }^{38}$ as the reason behind the sculptor's

\footnotetext{
${ }^{36}$ In the original publication, FdeD IV:2, 157-158, no suggestion is made as to the position of the missing left arm of "Athena." Poulsen (Delphi r 09) writes: "Athena . . . has seized the two combatants by the wrist, and seeks to separate them," but this comment rightly applies only in the case of Apollo. Some traces on Herakles' left shoulder, visible only in detailed photographs, could indicate the fingers of Zeus. Or his missing hand could have grasped the tripod behind the hero's head. Also the upper left "corner" of the tripod bowl shows unexplained marks, presumably a dowel for the attachment of one of the three ring handles. I owe this suggestion to Miss Jean Porter, now Mrs. Charles G. Nauert, of the University of Missouri.

37 This projection is not mentioned in the description of $F d e D$ IV:2, 156-157. I am extremely grateful to Prof. E. Vanderpool of the American School for Classical Studies in Athens, and
}

choice of an axial figure. By facing toward his right, the personage links the left wing of the pediment with the right wing, toward which his profiled feet point. The drawing, pl. 2, fig. $4{ }^{39}$ which takes into account the outline of the break at the neck as far as visible in the photograph, shows this to be a plausible reconstruction.

That the head was thus turned is perhaps confirmed by the uneven level of the frontal locks, the right "wedge" being shorter than the left one as if pulled back by a torsional movement. This correct observation of the behavior of hair is not too sophisticated for the archaic period, since the sculptors at work on the Treasury seem to have been particularly attentive to such details. Many of the combatants on the north frieze, for instance, have their hair arranged according to the dictates of gravitation and movement. Furthermore, on the frieze in general, personages with frontal torso and profile head display only one group of long locks over the chest, instead of the customary two; ${ }^{40}$ the indication of both parotides in the central pedimental figure might have been determined by the deity's more frontal "function," in spite of his twisted pose, while allowance was made for the torsion of the head through the unequal length of the locks.

If the central figure of the Siphnian pediment is indeed Zeus, why have so many scholars unanimously identified it as Athena? The answer lies perhaps in our tendency to equate sculpture with vase painting. ${ }^{41}$ In the ceramic repertoire the myth of The Struggle for the Tripod has a prominent place. Brommer, ${ }^{42}$ in his investigation of all known vases illustrating this subject, lists rro Attic black-figure examples, 32 red-figure ones, 4 archaic non-Attic vases and 5 post-archaic non-Attic. He does not, however, specify the various types of representation. Before him, Luce, ${ }^{43}$ who had knowledge of almost as many examples $^{44}$ and subdivided them typologically, listed

to Miss N. Bookidis, Bryn Mawr Ella Riegel Fellow to Greece, for checking, on my behalf, this detail, as well as several others, on the original monument.

38 See supra, n. II.

${ }^{39}$ For this drawing, as well as for stimulating discussion and suggestions, I am deeply indebted to Miss Jean Porter, now Mrs. Charles G. Nauert, of the University of Missouri.

${ }^{40}$ Cf., e.g., Ares and Zeus in the East Frieze, Delphes pl. 76.

${ }^{41}$ Lapalus, op.cit. (supra n. 7) 272, writes: “. . . dans le petits frontons, l'artiste grec du VIme siècle cherche à placer une image, beaucoup plus qu'à décorer; il emprunte ses thèmes à un répertoire, qui est aussi celui du céramiste, sans faire effort pour adapter au cadre tympanal le dispositif du thème utilizé."

42 Op.cit. (supra n. 9).

43 Op.cit. (supra n. 9).

${ }^{44}{ }_{1} 38$ as against Brommer's $15 \mathrm{I}$. However, Brommer has 
67 vases including Athena in the composition, as against 69 which did not, and of the latter group many showed only the two principal characters. It would therefore seem that, when a complex scene with more than the two actors is employed, Athena is an almost fixed element of the composition. By contrast, Zeus appears in only two of Luce's items, ${ }^{45}$ in scenes that include the greatest number of participants: Athena, Artemis and Hermes, besides Herakles and Apollo. On the basis of these statistics, Athena would seem the most likely identification for the central figure of the Siphnian pediment. Yet the vases listed are almost exclusively Attic, and it is understandable that Athenian painters would tend to represent their patron goddess, especially in connection with Herakles with whom she was so often associated. No such consideration applies to the unknown masters of the Siphnian Treasury, who were probably non-Athenians, even if not necessarily Siphnians or Ionians.

In summary, I submit that the central personage of the Siphnian pediment represents Zeus and not Athena, as is generally believed. The long dress and locks of the deity are no obstacle, since these fashions are appropriate to both male and female figures; indeed ankle-length chiton and short sleeves may indicate a masculine rather than a feminine garb, while parotides, on the evidence of the frieze, seem more commonly employed for gods than for goddesses. The lack of distinctive attributes, some-

been unable to trace 25 of Luce's references, so the two lists may in effect be considerably different.

45 Nos. 125-126. Since, however, Brommer does not describe composition, and many items in his list are either unpublished or difficult to verify, the number of scenes including Zeus may what unusual if the central divinity were Athena, is not significant in the case of Zeus, since greater stature and prominent position automatically emphasize his supremacy. Zeus's function as judge and mediator between the two litigants is attested by tradition and literary sources. Finally, some traces on the chest of the central figure seem to be the remains of a beard which would conclusively prove the suggested identification.

Zeus in the central position of the pediment also obviates the difficulty of scale involved in identifying the central deity as Athena. Zeus understandably towers over Herakles and Apollo, who, in their turn, are taller than the female figures (Artemis and Athena?) ${ }^{46}$ near them; the latter, because of their divine nature, might conceivably be taller than the mortals they accompany (Iolaos? in front of Athena, behind the right-wing horses; and two unidentified figures at the left). The diminishing scale of the personages in the center may thus be justified. No such justification exists for the diminutive horses and the other elements of the pedimental decoration: the general composition admittedly remains awkward and disjointed. Yet a central Zeus would at least provide a plausible central design, and add one more argument in support of the theory that sees in this modest pediment a forerunner of the Olympia sculptures.

BRYN MAWR COLLEGE

be larger.

46 The female figure to the right of Herakles presents several attachment holes on arm and chest, presumably for the addition of an aegis. 


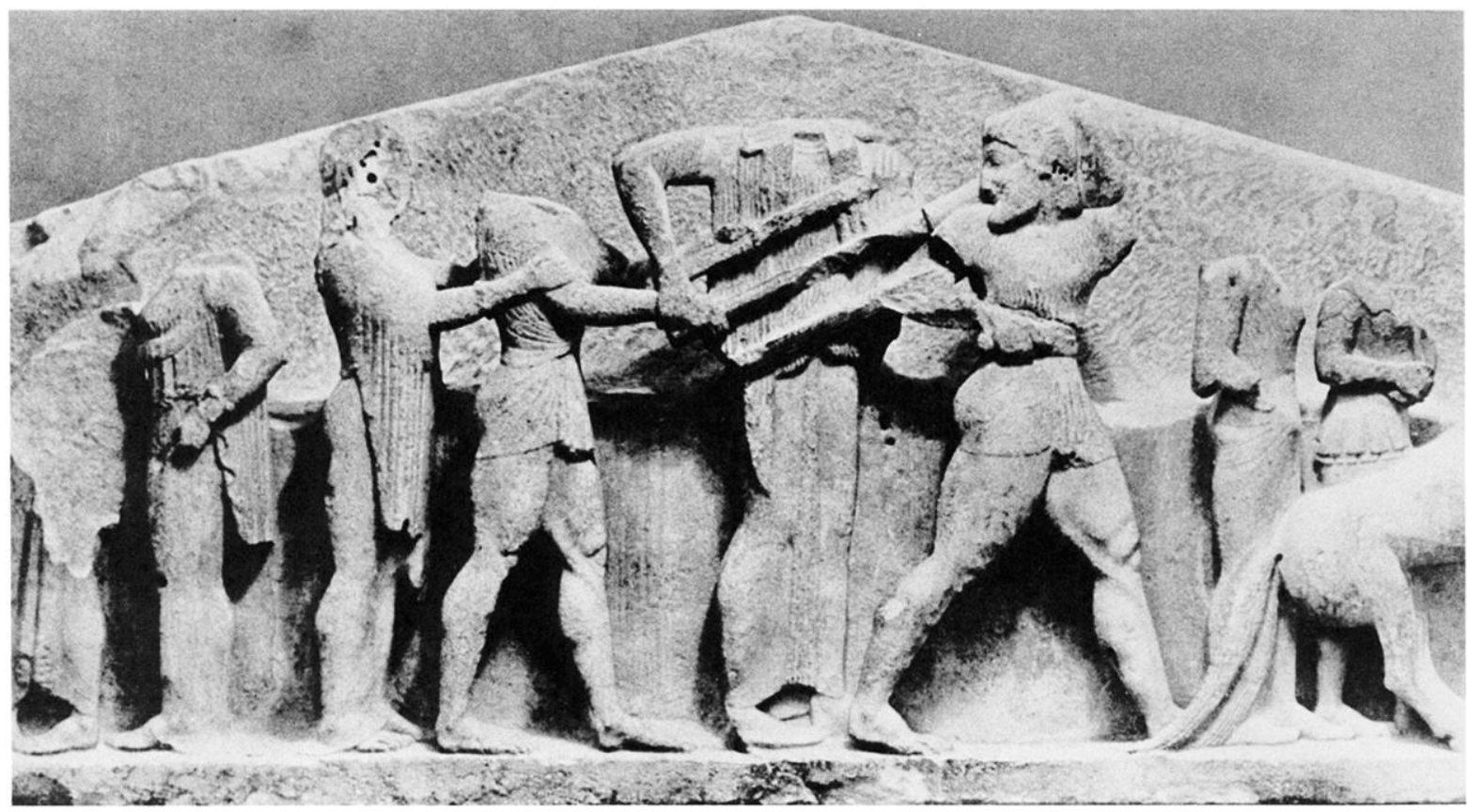

FIG. 2

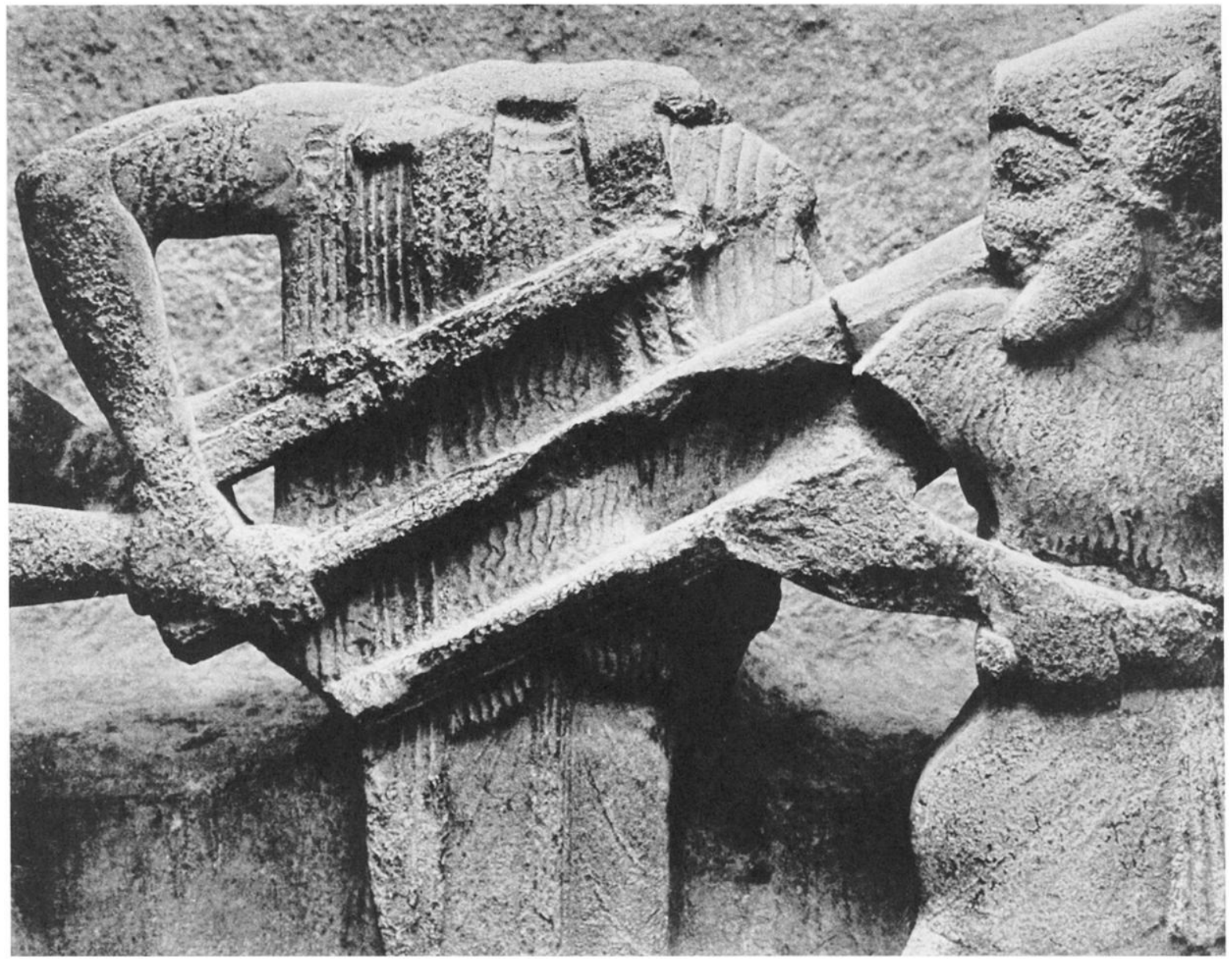

FIG. 3 

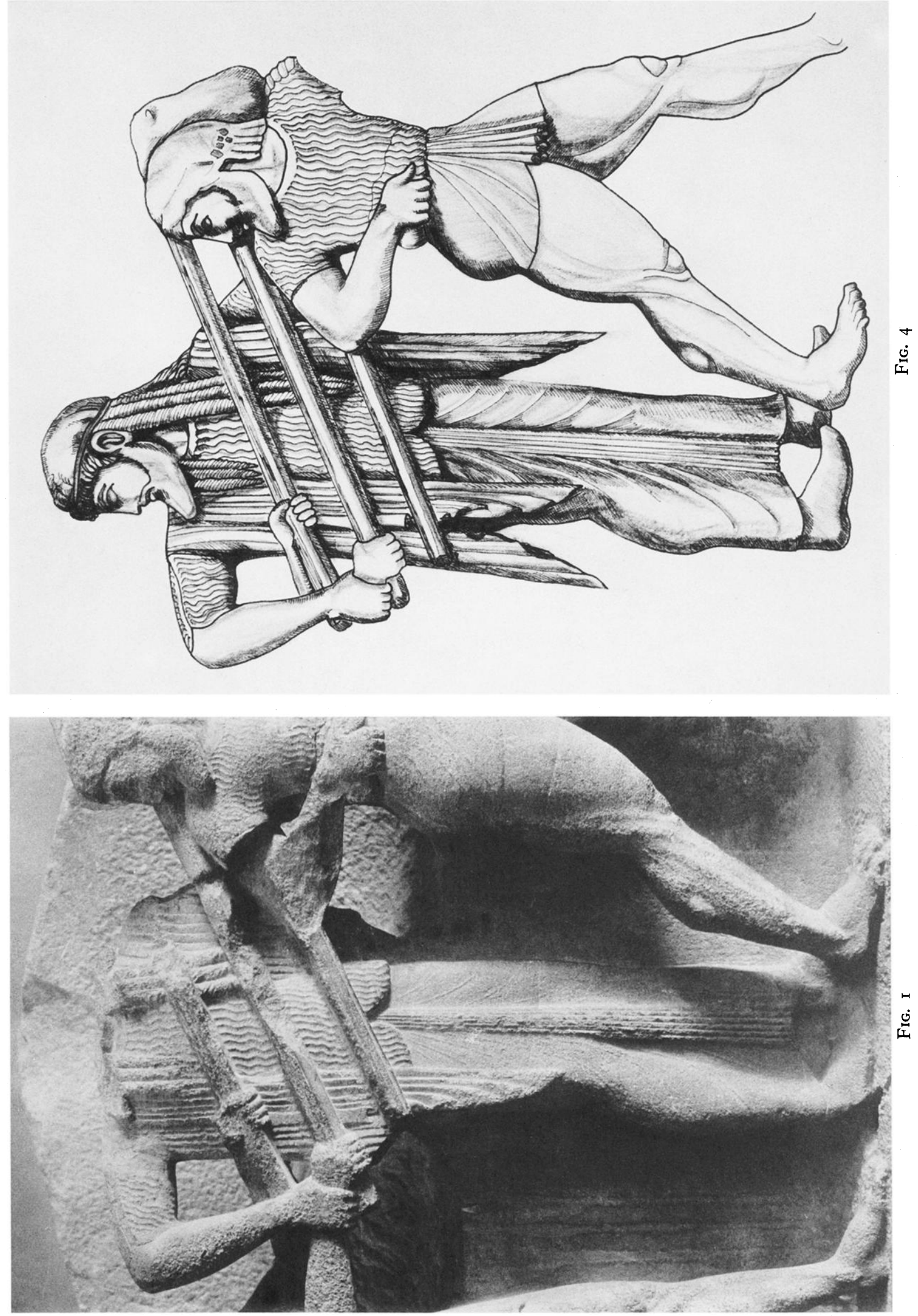